\title{
PERSEPSI PENGGUNA MODA TRANSPORTASI TERHADAP PENGGUNAAN BAHASA DI RUANG PUBLIK DI SEMBILAN KOTA INDONESIA
}

\author{
(Moda Transportation User Perception of Language Use in Public Spaces in Nine Cities \\ of Indonesia)
}

\author{
Amran Purba \\ Badan Pengembangan Bahasa dan Perbukuan \\ Pos-el: amran_purba61@gmail.com \\ tanggal naskah masuk 5 Maret 2019 \\ tanggal akhir penyuntingan 16 Juni 2019
}

\begin{abstract}
This study aims to determine the perceptions of users of transportation modes on language use at airports, stations, terminals, and ports in nine cities in Indonesia and to find out how far the application of language usage rules is applied to transportation modes. The method used in this study is a quantitative and descriptive qualitative approach. The research data is carried out by primary data collection in the field, namely the perception (view) of the users of transportation modes at airports, stations, terminals, and ports. The results of the study show that there are six cities (still dominant) agreeing on the use of Indonesian in the modes of air, sea, land and rail transportation. Then, there are two cities that even strongly agree on the use of Indonesian in the mode of transportation. Furthermore, there is one city that states that it is not agreeable to use Indonesian. Thus, perceptions of language users in transportation modes predominantly have high weight values. So, users of the transportation mode still have the concern to maintain or prioritize the use of Indonesian instead of foreign languages. Meanwhile, regional languages can also be used as a third language in the area rather than in the capital city.
\end{abstract}

Keywords: perception, mode of transportation, public space

\begin{abstract}
Abstrak
Penelitian ini bertujuan untuk mengetahui persepsi pengguna moda transportasi terhadap penggunaan bahasa di bandara, stasiun, terminal, dan pelabuhan di sembilan kota di Indonesia dan untuk mengetahui seberapa jauh penerapan aturan penggunaan bahasa diterapkan pada moda transportasi. Metode yang dilakukan dalam penelitian ini adalah pendekatan kuantitatif dan kualitatif deskriptif. Data penelitian ini dilakukan dengan pengambilan data primer di lapangan, yakni persepsi (pandangan) para pengguna moda transportasi di bandara, stasiun, terminal, dan pelabuhan. Hasil penelitian menunjukkan bahwa ada enam kota (masih dominan) menyatakan setuju tentang penggunaan Bahasa Indonesia di moda transportasi udara, laut, darat, dan kereta api. Kemudian, ada dua kota bahkan menyatakan sangat setuju penggunaan Bahasa Indonesia di moda transportasi. Selanjutnya, ada satu kota yang menyatakan kurang setuju penggunaan bahasa Indonesia. Dengan demikian, persepsi pengguna bahasa pada moda transportasi secara dominan memiliki nilai bobot yang tinggi. Jadi, pengguna moda transportasi itu masih memiliki kepedulian untuk mempertahankan atau mengutamakan penggunaan Bahasa Indonesia bukan bahasa asing. Sementara itu, bahasa daerah dapat juga digunakan sebagai bahasa ketiga di daerah bukan di ibu kota.
\end{abstract}

Kata-kata kunci: persepsi, moda transportasi, ruang publik 


\section{PENDAHULUAN}

Dewasa ini penggunaan bahasa Indonesia di ruang publik sudah banyak menarik khalayak ramai untuk diperbincangkan. Selain semakin meningkatnya kesadaran berbahasa yang baik, sosialisasi pelaksanaan UndangUndang No. 24 Tahun 2009 tentang Bendera, Bahasa, dan Lambang Negara, serta Lagu Kebangsaan pun menjadi landasan banyak orang untuk menggunakan bahasa Indonesia di samping bahasa daerah dan bahasa asing.

\section{Dalam buku Petunjuk Teknis} Pengutamaan Penggunaan Bahasa Negara di Ruang Publik Tahun 2018 disebutkan bahwa ruang publik tidak terbatas pada bahasa yang berada di area umum atau media luar ruang, tetapi juga pada bahasa yang digunakan atau dihasilkan pada ruang publiknya (Kemdikbud, 2018). Bahasa yang dimaksud dalam pernyataan itu adalah bahasa Indonesia sebagai bahasa negara sebagai sarana berkomunikasi dalam ragam resmi.

Dari pernyataan-pernyataan itulah muncul permasalahan yang berangkat dari pandangan masyarakat terhadap penggunaan bahasa Indonesia di ruang publik. Bagaimana pandangan masyarakat terhadap penggunaan bahasa Indonesia di ruang publik? Dalam hal ini wilayah ruang publik dibatasi pada wilayah yang berhubungan dengan moda transportasi, yaitu bandara, stasiun, terminal, dan pelabuhan, sedangkan masyarakat yang dimaksud adalah pengguna moda transportasi.

Masalah yang akan dibahas dalam penelitian ini adalah pandangan (sikap bahasa) pengguna moda transportasi terhadap penggunaan bahasa ruang publik di bandara, stasiun, terminal, dan pelabuhan di beberapa kota. Bagaimanakah pendangan atau persepsi pengguna bahasa terhadap penggunaan bahasa pada moda transportasi? Apakah penggunaan bahasa pada moda transportasi di beberapa kota sudah sesuai dengan kaidah atau undangundang bahasa yang berlaku?

Tujuan yang akan dihasilkan dalam penelitian ini adalah untuk mengetahui pandangan atau persepsi pengguna moda transportasi terhadap penggunaan bahasa di bandara, stasiun, terminal, dan pelabuhan di beberapa kota yang ada di Indonesia. Mengetahui seberapa jauh penerapan aturan bahasa diterapkan terhadap moda transportasi. Menambah kekayaan penelitian di bidang kebahasaan khususnya pemakaian bahasa Indonesia ruang publik pada moda transportasi di Indonesia. Memperluas khazanah pemahaman bahasa khususnya penyimpangan bahasa ruang publik pada moda transportasi di Indonesia. Manfaat praktis bagi Badan Bahasa, yaitu memberikan rekomendasi bagi pemegang kebijakan Badan Bahasa dalam membuat atau perbaikan program pembinaan dan pengembangan kebahasaan. Sementara bagi Pemerintah Ibu Kota dan Provinsi, memberikan masukan untuk bahan kebijakan kepada Pemerintah Ibu Kota dan Provinsi selaku pemangku kepentingan tentang aturan pemakaian bahasa Indonesia ruang publik pada moda transportasi di Indonesia.

\section{LANDASAN TEORETIS}

Menurut (TBBI 2018:13) bahasa baku mendukung empat fungsi, yaitu (1) fungsi pemersatu, (2) fungsi pemberi kekhasan, (3) fungsi pembawa kewibawaan, dan (4) fungsi sebagai kerangka acuan. Tiga di antaranya bersifat pelambang atau simbolik, sedangkan yang satu lagi bersifat objektif.

Bahasa baku memperhubungkan semua penutur berbagai dialek bahasa itu. Dengan demikian, bahasa baku mempersatukan mereka menjadi satu masyarakat bahasa dan meningkatkan proses identifikasi penutur orang seorang dengan seluruh mayarakat.

Jika bahasa sudah baku dan standar, baik yang ditetapkan secara resmi lewat 
surat putusan pejabat pemerintah atau maklumat, maupun yang diterima berdasarkan kesepakatan umum dan yang wujudnya dapat kita saksikan pada praktik pengajaran bahasa kepada khalayak. Hal itu dapat dengan lebih mudah dibuat pembedaan antara bahasa yang benar dengan yang tidak. Pemakaian bahasa yang mengikuti kaidah yang dibakukan atau yang dianggap baku itulah yang merupakan bahasa yang benar.

Penelitian ini bertolak dari data penelitian berupa jawaban responden atas pertanyaan-pertanyaan yang diajukan melalui kuesioner. Dengan kata lain, objek penelitian ini adalah tanggapan yang berisikan persepsi responden terhadap penggunaan bahasa asing di ruang publik.

Berikut ini disajikan beberapa pengertian persepsi. Umumnya istilah persepsi digunakan dalam bidang psikologi. Secara terminologi sebagaimana dinyatakan Purwodarminto (1990: 759), pengertian persepsi adalah tanggapan langsung dari suatu serapan atau proses seseorang mengetahui beberapa hal melalui pengindraan. Kamus besar psikologi, persepsi diartikan sebagai suatu proses pengamatan seseorang terhadap lingkungan dengan menggunakan indra-indra yang dimiliki sehingga ia menjadi sadar akan segala sesuatu yang ada dilingkungannya.

Menurut Asrori

(2009:214)

pengertian persepsi adalah "proses individu dalam menginterprestasikan, mengorganisasikan, dan memberi makna terhadap stimulus yang berasal dari lingkungan di mana individu itu berada yang merupakan hasil dari proses belajar dan pengalaman." Dalam pengertian persepsi tersebut terdapat dua unsur penting, yakni interprestasi dan pengorganisasian. Interprestasi merupakan upaya pemahaman dari individu terhadap informasi yang diperolehnya, sedangkan perorganisasian adalah proses mengelola informasi tertentu agar memiliki makna.
Persepsi merupakan suatu proses yang dipelajari melalui interaksi dengan lingkungan sekitar. Persepsi sesorang timbul sejak kecil melalui interaksi dengan manusia lain. Sejalan dengan hal itu, Rahmat (1990:64) mendefiniskan persepsi sebagai: "pengalaman tentang objek, peristiwa atau hubungan-hubungan yang diperoleh dengan menyimpulkan informasi dan menafsirkan pesan". Kesamaan pendapat ini terlihat dari makna menyimpulkan informasi dan menafsirkan pesan yang memiliki keterkaitan dengan proses untuk memberi arti.

Menurut Slameto (2010:102) pengertian persepsi adalah proses yang berkaitan dengan masuknya pesan atau informasi ke dalam otak manusia, melalui persepsi manusia terus menerus mengadakan hubungan dengan lingkungannya. Hubungan ini dilakukan lewat inderanya, yaitu indera pengelihat, pendengar, peraba, perasa, dan pencium. Menurut Sarlito Wirawan Sarwono (1983: 89), persepsi adalah kemampuan seseorang untuk mengorganisasi suatu pengamatan, kemampuan tersebut antara lain: kemampuan untuk membedakan, kemampuan untuk mengelompokan, dan kemampuan untuk memfokuskan. Oleh karena itu, seseorang bisa saja memiliki persepsi yang berbeda, walaupun objeknya sama. Hal tersebut dimungkinkan karena adanya perbedaan dalam hal sistem nilai dan ciri kepribadian individu yang bersangkutan. Menurut Irwanto (1991:71) pengertian persepsi adalah proses diterimanya rangsang (objek, kualitas, hubungan antargejala, maupun peristiwa) sampai rangsang itu disadari dan dimengerti. Reaksi seseorang terhadap suatu objek dapat diwujudkan dalam bentuk sikap atau tingkah laku seseorang tentang apa yang dipersepsikan.

Menurut Robbins (1999:124) pengertian persepsi merupakan kesan yang diperoleh oleh individu melalui panca indera kemudian dianalisis (diorganisasi), diintepretasi dan kemudian dievaluasi 
sehingga individu tersebut memperoleh makna. Sementara itu, Thoha (1999:123-1 24), pengertian persepsi pada hakikatnya adalah proses kognitif yang dialami oleh setiap orang dalam memahami setiap informasi tentang lingkungannya, baik melalui penglihatan, pendengaran, penghayatan, perasaan, dan penciuman.

\section{METODOLOGI PENELITIAN}

Metode yang dilakukan dalam penelitian ini adalah dengan pendekatan kuantitatif dan kualitatif deskriptif. Data penelitian ini dilakukan dengan pengambilan data primer di lapangan, yakni persepsi (pandangan) para pengguna moda transportasi di bandara, stasiun, terminal, dan pelabuhan.

\section{Survei tentang persepsi}

(pandangan) pengguna moda transportasi terhadap penggunaan bahasa Indonesia di ruang publik juga dilakukan dengan menggunakan metode representasi sosial. Metode itu dilakukan dengan cara mewawancarai responden. Responden dalam survei ini adalah masyarakat yang berhubungan dengan para pengguna moda transportasi di bandara, setasiun, terminal, dan pelabuhan. Selain itu, penelitian ini juga menggunakan kuesioner yang berpedoman pada skala likert untuk mengetahui sikap bahasa masyarakat kota. Angket yang didistribusikan adalah butir angket dalam bentuk pilihan berganda (multiple choice) dengan lima buah opsi pilihan jawaban dengan bobot skala 5,4,3,2, dan 1 . Opsi yang memiliki bobot 5 berarti sikap responden terhadap bahasa Indonesia semakin positif, sedangkan opsi yang mengandung bobot 1 berarti sikap responden terhadap bahasa Indonesia sangat negatif. Setiap satu butir angket memiliki opsi pilihan jawaban ss, s, ks, ts, dan sts, yang masing-masing memiliki bobot $5,4,3,2$, atau 1 . Oleh karena itu, responden yang memperoleh nilai angket dengan bobot yang tinggi mengindikasikan sikapnya terhadap bahasa Indonesia semakin positif. Sebaliknya, responden yang memperoleh nilai angket dengan bobot yang rendah, sikapnya terhadap bahasa Indonesia semakin negatif.
Penelitian ini menggunakan teknik sampling secara acak (random sampling) yang menjadi responden. Peneliti mencari responden di tempat moda transportasi digunakan dengan tidak memilah-milah responden. Teknik yang digunakan pertama respoden yang memiliki waktu lalu diwawancarai dan responden yang diminta untuk mengisi kuesioner. Sementara itu, metode tersebut adalah cara untuk mendapatkan informasi dan membuat lawan berbicara tentang sebuah subjek atau tema yang jelas sebagaimana yang hendak diteliti (Permanadeli, 2015). Berdasarkan teknik pengumpulan data, dalam penelitian ini digunakan dua macam data, yaitu data primer dan data sekunder. Data primer diperoleh melalui survey, sedangkan data sekunder diperoleh dari dokumen.

Penelitian survei tentang Pandangan atau Persepsi Pengguna Moda Transportasi terhadap Penggunaan Bahasa di Ruang Publik dilaksanakan di Medan, Surabaya, Denpasar, Makassar, Maluku, Palangka Raya. Papua, Palembang, dan Manado dan dilakukan pada bulan MaretMei 2018.

\section{PEMBAHASAN}

Melalui analisis data terhadap 155 responden perempuan (P: 90) dan laki-laki (L: 65) diperoleh simpulan bahwa secara umum tidak ada perbedaan yang signifikan.

Jawaban responden terhadap kuesioner yang dibagikan di tujuh kota adalah dominan menyatakan sangat setuju untuk penggunaan Bahasa Indonesia. Di dua kota menyatakan sangat setuju dan setuju berimbang. Di Sembilan kota itu tidak ada yang tidak setuju dan sangat tidak setuju. Hal itu dapat dilihat dala digram berikut. 


\begin{tabular}{|l|l|l|l|l|l|l|}
\hline No. & \multicolumn{1}{|c|}{ Kota } & \multicolumn{1}{c|}{ SS } & \multicolumn{1}{c|}{ S } & \multicolumn{1}{c|}{ KS } & TS & STS \\
\hline 1. & Surabaya & 22 & 8 & & & \\
\hline 2 & Medan & 20 & 10 & & & \\
\hline 3 & Menado & 15 & 5 & & & \\
\hline 4 & Makassar & 9 & 2 & & & \\
\hline 5 & Palembang & 7 & 4 & & & \\
\hline 6 & Denpasar & 4 & 5 & & & \\
\hline 7 & Palangka Raya & 11 & 4 & & & \\
\hline 8 & Papua & 13 & 2 & & & \\
\hline 9 & Maluku & 6 & 6 & 1 & & \\
\hline
\end{tabular}

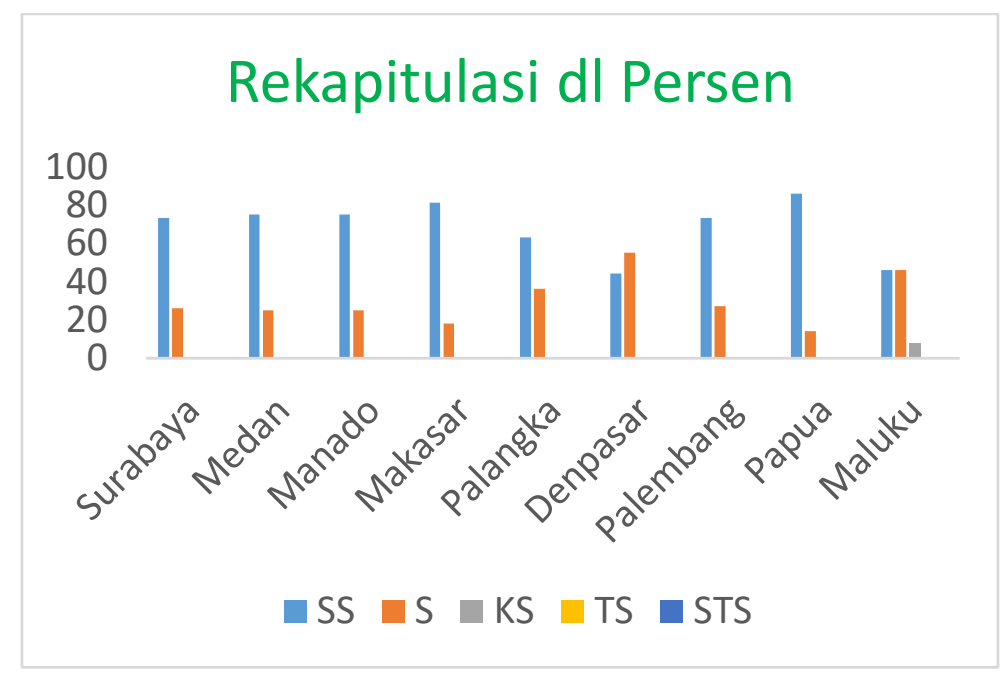

Berdasarkan data yang dibuat oleh responden, rekapitulasi jawaban responden terhadap kuesioner yang dibagikan di sembilan kota adalah sebagai berikut.

1. Berdasarkan jawaban itu terlihat dengan jelas bahwa pengguna transportasi di Kota Surabaya menyatakan sangat setuju 87 (24\%), setuju 139 (39\%), kurang setuju $70(19,6 \%)$, tidak setuju 37 $(10 \%)$, dan $23(6 \%)$ sangat tidak setuju.

2. Berdasarkan jawaban itu terlihat dengan jelas bahwa pengguna transportasi di Kota Medan menyatakan sangat setuju 113 (31\%), setuju $115(31,6 \%)$, kurang setuju $84(23 \%)$, tidak setuju 35
$(9,6 \%)$, dan $6(1,6 \%)$ sangat tidak setuju.

3. Berdasarkan jawaban itu terlihat dengan jelas bahwa pengguna transportasi di Kota Manado menyatakan sangat setuju 47 (20\%), setuju 105 (44,6\%), kurang setuju $46(19,5 \%)$, tidak setuju 30 $(12,7 \%)$, dan $7(2,9 \%)$ sangat tidak setuju

4. Berdasarkan jawaban itu terlihat dengan jelas bahwa pengguna transportasi di Kota Makasar menyatakan sangat setuju $41(31 \%)$, setuju $34 \quad(25,7 \%)$, kurang setuju 21 (15,9\%), tidak setuju $25(18,9 \%)$, dan $11(8 \%)$ sangat tidak setuju. 
5. Berdasarkan jawaban itu terlihat dengan jelas bahwa pengguna transportasi di Kota Palangka Raya menyatakan sangat setuju 33 (25\%), setuju 38 (28,7\%), kurang setuju $39(29,5 \%)$, tidak setuju 18 $(13,6 \%)$, dan $4(3 \%)$ sangat tidak setuju.

6. Berdasarkan jawaban itu terlihat dengan jelas bahwa pengguna transportasi di Kota Denpasar menyatakan sangat setuju 23 (21\%), setuju $39(36, \%)$, kurang setuju $27(25 \%)$, tidak setuju 11 $(10 \%)$, dan $8(7 \%)$ sangat tidak setuju.

7. Berdasarkan jawaban itu terlihat dengan jelas bahwa pengguna transportasi di Kota Palembang menyatakan sangat setuju 47 (23\%), setuju 60 (30,6\%), kurang setuju $58(29,5 \%)$, tidak setuju 21 $(10,7 \%)$, dan $10(5 \%)$ sangat tidak setuju.

8. Berdasarkan jawaban itu terlihat dengan jelas bahwa pengguna transportasi Papua menyatakan sangat setuju $47(26 \%)$, setuju 42 $(23,5 \%)$, kurang setuju 38 (21\%), tidak setuju $26(14,6 \%)$, dan 25 (14\%) sangat tidak setuju.

9. Berdasarkan jawaban itu terlihat dengan jelas bahwa pengguna transportasi Maluku menyatakan sangat setuju $36(23,5 \%)$, setuju $58(37,9 \%)$, kurang setuju 40 (26\%), tidak setuju 15 (9,8\%), dan $4(2,6 \%)$ sangat tidak setuju

TABEL: REKAPITULASI

\begin{tabular}{|l|c|c|c|c|c|l|}
\hline No. & SS & S & KS & \multicolumn{1}{|c|}{ TS } & \multicolumn{1}{|c|}{ STS } & Kota \\
\hline 1 & $87(24 \%)$ & $139(39 \%)$ & $70(19,6 \%$ & $37(10 \%)$ & $23(6 \%)$ & Surabaya \\
\hline 2 & $113(31 \%)$ & $115(31,6 \%$ & $84(23 \%)$ & $35(9,6 \%)$ & $6(1,6 \%)$ & Medan \\
\hline 3 & $47(20 \%)$ & $105(44,6 \%)$ & $46(19,5 \%)$ & $30(12,7 \%)$ & $7(2,9 \%$ & Manado \\
\hline 4 & $41(31 \%)$ & $34(25,7 \%)$ & $21(15,9 \%)$ & $25(18,9 \%)$ & $11(8 \%)$ & Makasar \\
\hline 5 & $33(25 \%)$ & $38(28,7 \%$ & $39(29,5 \%)$ & $18(13,6 \%)$ & $4(3 \%)$ & Palangka \\
\hline 6 & $23(21 \%)$ & $39(36, \%)$ & $27(25 \%)$ & $11(10 \%)$ & $8(7 \%)$ & Denpasar \\
\hline 7 & $47(23 \%)$ & $60(30,6 \%)$ & $58(29,5 \%)$ & $21(10,7 \%)$ & $10(5 \%)$ & Palembang \\
\hline 8 & $47(26 \%)$ & $42(23,5 \%)$ & $38(21 \%)$ & $26(14,6 \%)$ & $25(14 \%)$ & Papua \\
\hline 9 & $36(23,5 \%)$ & $58(37,9 \%)$ & $40(26 \%)$ & $15(9,8 \%)$ & $4(2,6 \%)$ & Maluku \\
\hline & & & & & & \\
\hline
\end{tabular}




\section{Rekapitulasi dl Persen}

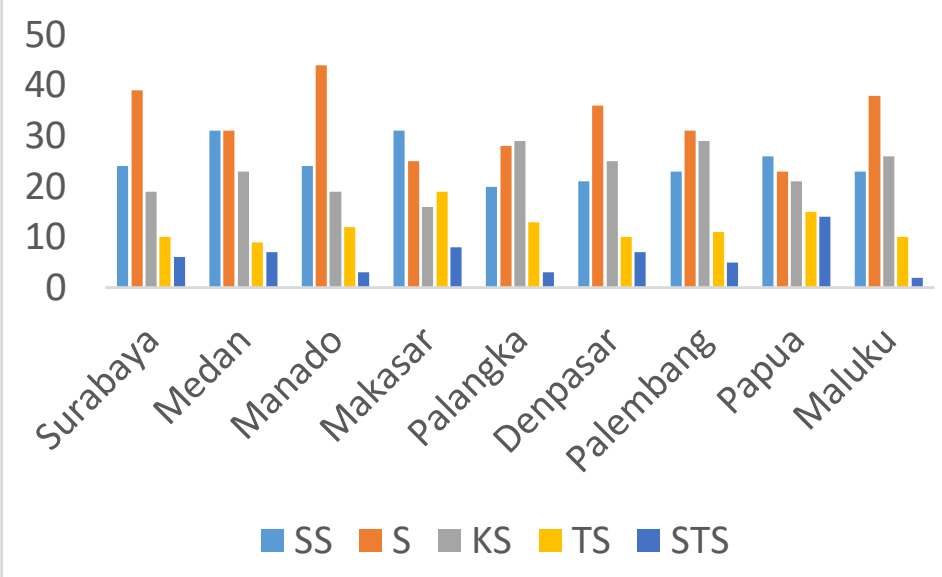

\section{Tanggapan responden di tiga wilayah}

Tanggapan responden tentang penggunaan bahasa asing di ruang publik ranah transportasi, seperti terminal, stasiun, pelabuhan, dan bandara adalah sebagai berikut. Ada empat puluh responden yang menyatakan kesetujuannya terhadap penggunaan bahasa asing di ruang publik ranah transportasi, seperti terminal, stasiun, pelabuhan, dan bandara karena untuk memudahkan orang asing memahami petunjuk arah. Namun, sebagian besar responden tetap menghendaki penggunaan bahasa Indonesia di samping bahasa asing itu. Ada sembilan belas responden yang menyatakan ketidaksetujuan terhadap penggunaan bahasa asing di ruang publik ranah transportasi, seperti terminal, stasiun, pelabuhan, dan bandara karena mengakui bahwa bahasa Indonesia tetap lebih baik digunakan untuk bahasa media luar ruang. Hal ini sejalan dengan penelitian yang dilakukan oleh Permanadedi, dkk. bahwa bahasa Inggris dipersepsikan sebagai sarana dan tanda teperolehnya status sosial baru: modern dan berkelas (Permanadedi dkk., 2016: 13).

Dari tiga kota yang dikunjungi peneliti, hanya Bandara Internasional Sam Ratulangi, Manado yang ada menggunakan bahasa daerah, baik untuk ragam tulis dan lisan. Penggunaan bahasa asing, seperti bahasa Inggris (dengan aksara Latin), bahasa Arab (dengan aksara Arab), dan bahasa Tiongkok (dengan aksara Han) juga terdapat di bandara Sam Ratulangi, Manado, di bandara Kualanamu, Medan, dan di Bandara Juanda (Terminal 2), Surabaya.

Dari tiga kota yang dikunjungi peneliti, hanya terminal Purabaya, Surabaya yang memiliki petunjuk arah yang teratur dan komunikatif. Terminal di Medan dan Manado belum memiliki penunjuk arah yang yang teratur dan komunikatif. Para petugas terminal beralasan bahwa terminal sudah sering digunakan masyarakat setempat sehingga tidak membutuhkan petunjuk arah. Walaupun demikian, mereka dengan senang hati akan mengikuti sosialisasi tentang penggunaan bahasa Indonesia di ruang publik ranah transportasi jika pihak Balai Bahasa setempat mengadakannya.

Di Pelabuhan Penumpang Bandar Deli, Medan peneliti tidak mendapatkan responden, baik calon penumpang kapal laut, maupun petugas pelabuhan. Hal ini dikarenakan kedatangan peneliti bukan saat kapal datang atau saat keberangkatan penumpang. Petugas Pelindo I pun tidak berani menerima peneliti karena belum ada izin dari kantor pusat yang letaknya berjauhan dari pelabuhan. Hal ini sangat 
disayangkan, mengingat banyaknya penggunaan bahasa Inggris yang tidak disertai bahasa Indonesia di sekitar pelabuhan itu. Sementara itu, di pelabuhan lain di wilayah Manado dan Surabaya penggunaan bahasa Indonesianya sudah cukup baik.

Penggunaan bahasa Indonesia di stasiun kereta api di Medan dan Surabaya cukup baik, khususnya Medan, karena terintegrasi dengan bandara Kualanamu. Petunjuk arah di stasiun kereta api Bandara Kualanamu menggunakan empat bahasa, yaitu Indonesia, Inggris, Arab, dan Tiongkok.

\section{PENUTUP}

\section{Simpulan}

Dari penelitian ini yang berdasarkan kuesioner dapat diambil simpulan bahwa pengguna transportasi di sembilan kota adalah sebagai berikut. Ada enam kota (masih dominan) menyatakan setuju tentang penggunaan Bahasa Indonesia di moda transportasi udara, laut, darat, dan kereta api. Kemudian, ada dua kota bahkan menyatakan sangat setuju penggunaan Bahasa Indonesia di moda transportasi. Selanjutnya, ada satu kota yang menyatakan kurang setuju penggunaan bahasa Indonesia. Dengan demikian, pengguna bahasa pada moda transportasi secara dominan memiliki nilai bobot yang tinggi. Jadi, pengguna moda transportasi itu masih memiliki kepedulian untuk mempertahankan atau mengutamakan penggunaan Bahasa Indonesia bukan bahasa asing yang lebih utama. Sementara itu, bahasa daerah dapat juga digunakan sebagai bahasa ketiga di daerah bukan di ibu kota.

Hasil survei tentang pandangan (sikap bahasa) pengguna moda transportasi terhadap penggunaan bahasa di bandara, stasiun, terminal, dan pelabuhan ini adalah sebagai berikut:

1) Hasil pemantauan penggunaan bahasa diketahui di bandara memperlihatkan bahwa penggunaan bahasa asing masih tinggi, seperti Kualanamu

International Airport di Medan. Hal ini memperlihatkan bahwa UndangUndang Kebahasaan belum diterapkan dan belum diindahkan oleh kalangan bandara. Akan tetapi, ada bandara yang sudah menggunakan Bahasa Indonesia, seperti Bandara International Samratulangi di Manado. Sementara itu, di stasiun dan terminal keseluruhannya konsisten menggunakan bahasa Indonesia, sedangkan di pelabuhan masih terdapat menggunakan bahasa asing sebagai petunjuk informasi.

2) Pandangan atau persepsi pengguna moda transportasi adalah positif terhadap penggunaan bahasa diketahui di bandara, stasiun, terminal, dan pelabuhan masih menginginkan penggunaan bahasa Indonesia lebih diutamakan agar memperlihatkan jati diri bangsa.

3) Pandangan atau respons negatif terhadap bahasa pengguna moda transportasi terhadap penggunaan bahasa diketahui di bandara, sedangkan di stasiun, terminal, dan pelabuhan tidak demikian.

\section{Rekomendasi}

Berdasarkan hasil penelitian tim dapat dibuat rekomendasi sebagai berikut.

1. Pandangan atau respons positif pengguna moda transportasi terhadap penggunaan bahasa diketahui di bandara, stasiun, terminal, dan pelabuhan masih menginginkan penggunaan Bahasa Indonesia dipertahankan sebagai jati diri bangsa.

2. Penggunaan bahasa asing (Inggris) dapat digunakan setelah ada bahasa Indonesianya, sedangkan bahasa asing lain (Bahasa China atau Bahasa Arab) dapat digunakan bersifat temporal saja. 
3. Agar penggunaan bahasa di ruang publik dapat terkendali, Badan Pengembangan dan Pembinaan Bahasa perlu meningkatkan sosialisasi UU No. 24 Th 2009 Tentang Kebahasaan karena masih rendahnya aturan bahasa yang digunakan oleh pemangku kepentingan yang berkaitan dengan moda transportasi, terutama moda transportasi di bandara seluruh Indonesia.

\section{DAFTAR PUSTAKA}

Chaer, Abdul. (2009). Sintaksis Bahasa Indonesia (Pendekatan Proses). Jakarta: Rineka Cipta. (2006). Tata Bahasa Praktis Bahasa Indonesia. Jakarta: Rineka Utama
Halim, Amran. (1983). "Sikap Bahasa dan Pelaksanaan Kebijakan Bahasa Nasional". Jakarta: Depdikbud

Purba, Amran dkk. (2017). "Kajian penggunaan bahasa Indonesia di Pusat Perbelanjaan di DKI Jakarta." Laporan Penelitian di Pusat Pembinaan, Badan Pengembangan dan Pembinaan Bahasa.

Purba, Amran. (2017). Potret Penggunaan Bahasa di Ruang Publik Kota Medan. Medan: Penerbit MITRA.

Sugiyono. (2017). Metode Penelitian

Kombinasi. Bandung: Penerbit Alfabeta

Suhendar, Dadang el al. (2016). Kamus Besar Bahasa Indonesia. Edisi V. Jakarta: Badan Bahasa.

Suhendar, Dadang el al. (2017). Tata Bahasa Baku Bahasa Indonesia. Edisi IV. Jakarta: Badan Bahasa. 


\section{Kuesioner Pandangan Pengguna Moda Transportasi tentang Penggunaan Bahasa di Ruang Publik}

Penelitian ini merupakan penelitian bahasa yang dilaksanakan di Badan Pengembangan dan Pembinaan Bahasa. Penelitian ini dimaksudkan untuk mengetahui Pandangan Pengguna Moda Transportasi tentang Penggunaan Bahasa di Ruang Publik. Sehubungan dengan itu, kami mohon kesediaan Anda untuk menjadi responden penelitian ini. Anda tidak perlu menuliskan nama, tetapi kami sangat mengharapkan Anda mengisi kuesioner ini dengan sungguh-sungguh.

\begin{tabular}{|l|l|ll|}
\hline No. & \multicolumn{1}{|c|}{ A. Data Responden } & \multicolumn{2}{c|}{ Jawaban } \\
\hline 1 & Jenis kelamin (pilih salah satu) & OLaki-laki & ○ Perempuan \\
\hline 2 & Usia (pilih salah satu) & ODi bawah 25 Tahun & ○ Di atas 25 Tahun \\
\hline 3 & $\begin{array}{l}\text { Moda transportasi apa yang sudah } \\
\text { pernah Anda gunakan? (boleh menjawab } \\
\text { lebih dari satu) }\end{array}$ & $\begin{array}{l}\text { Bus/kereta api/kapal } \\
\text { laut/pesawat udara }\end{array}$ & \\
\hline
\end{tabular}

\section{B. Pandangan Pengguna Moda Transportasi tentang Penggunaan Bahasa di Ruang Publik}

Bagian ini berisi beberapa pernyataan yang berkaitan dengan pandangan pengguna moda transportasi terhadap penggunaan bahasa di ruang publik. Bubuhkan tanda centang (V) pada kolom pilihan Anda. SS jika Anda sangat setuju, S jika Anda setuju, KS jika Anda kurang setuju, TS jika Anda tidak setuju, dan STS jika Anda sangat tidak setuju.

\begin{tabular}{|l|l|l|l|l|l|l|}
\hline No. & Pernyataan & SS & KS & TS & STS \\
\hline 1 & $\begin{array}{l}\text { Kata/istilah Indonesia digunakan pada penunjuk arah di } \\
\text { terminal/stasiun/pelabuhan/bandara. }\end{array}$ & & & \\
\hline 2 & $\begin{array}{l}\text { Kata/istilah asing digunakan pada penunjuk arah di } \\
\text { terminal/stasiun/pelabuhan/bandara. } \\
\text { Kata/istilah asing yang digunakan di } \\
\text { terminal/stasiun/pelabuhan/bandara membuat kebanggaan bagi yang } \\
\text { membacanya. }\end{array}$ & & & & \\
\hline 4 & $\begin{array}{l}\text { Kata asing yang digunakan untuk keperluan usaha atau keperluan } \\
\text { pribadi sebenarnya hanya mengikuti tren. }\end{array}$ & & & & \\
\hline 5 & $\begin{array}{l}\text { Penggunaan kata-kata asing di terminal/stasiun/pelabuhan/bandara } \\
\text { sudah lazim. }\end{array}$ & & & \\
\hline
\end{tabular}




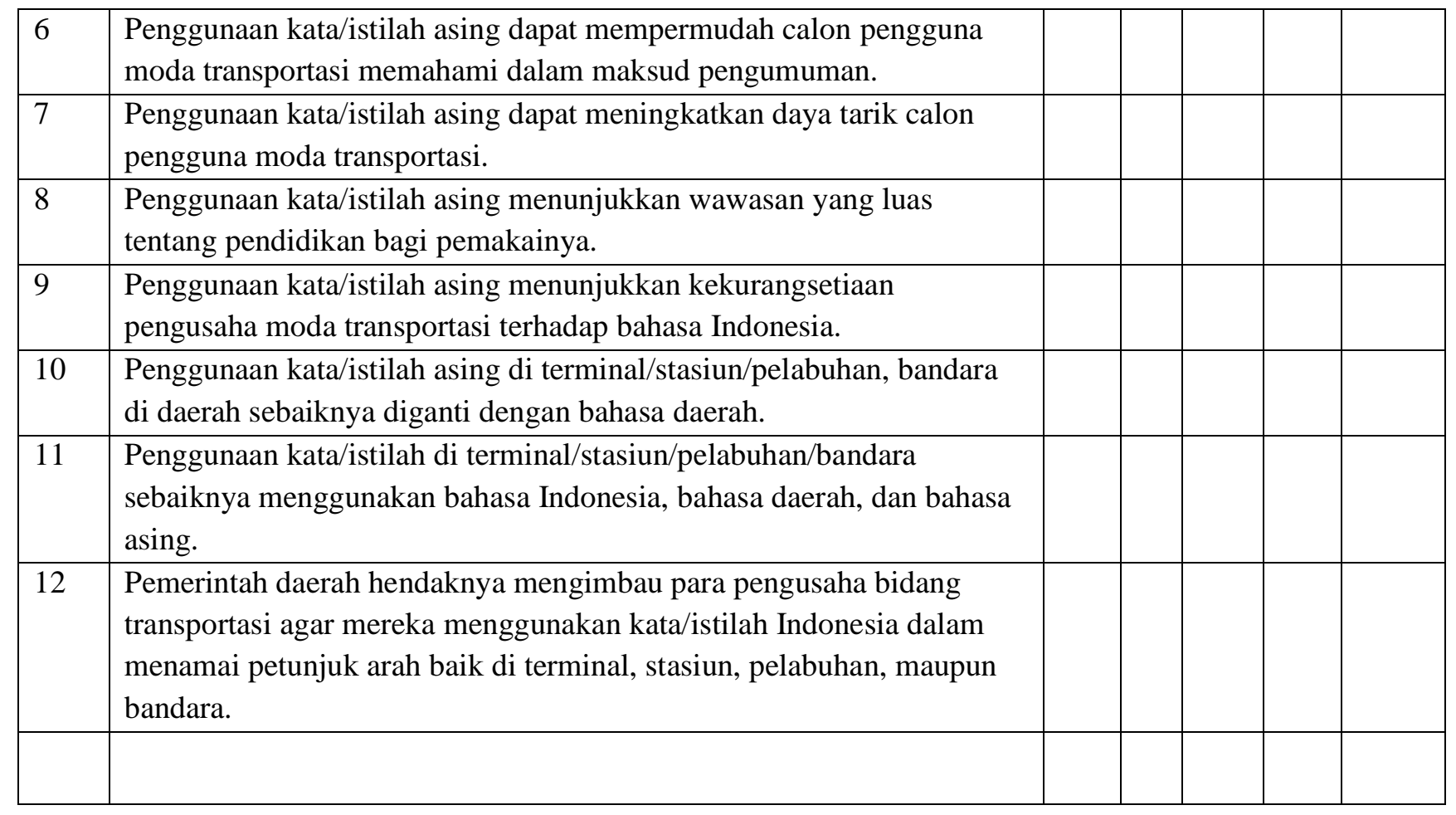

\section{Tanggapan tentang Penggunaan Bahasa di Ruang Publik}

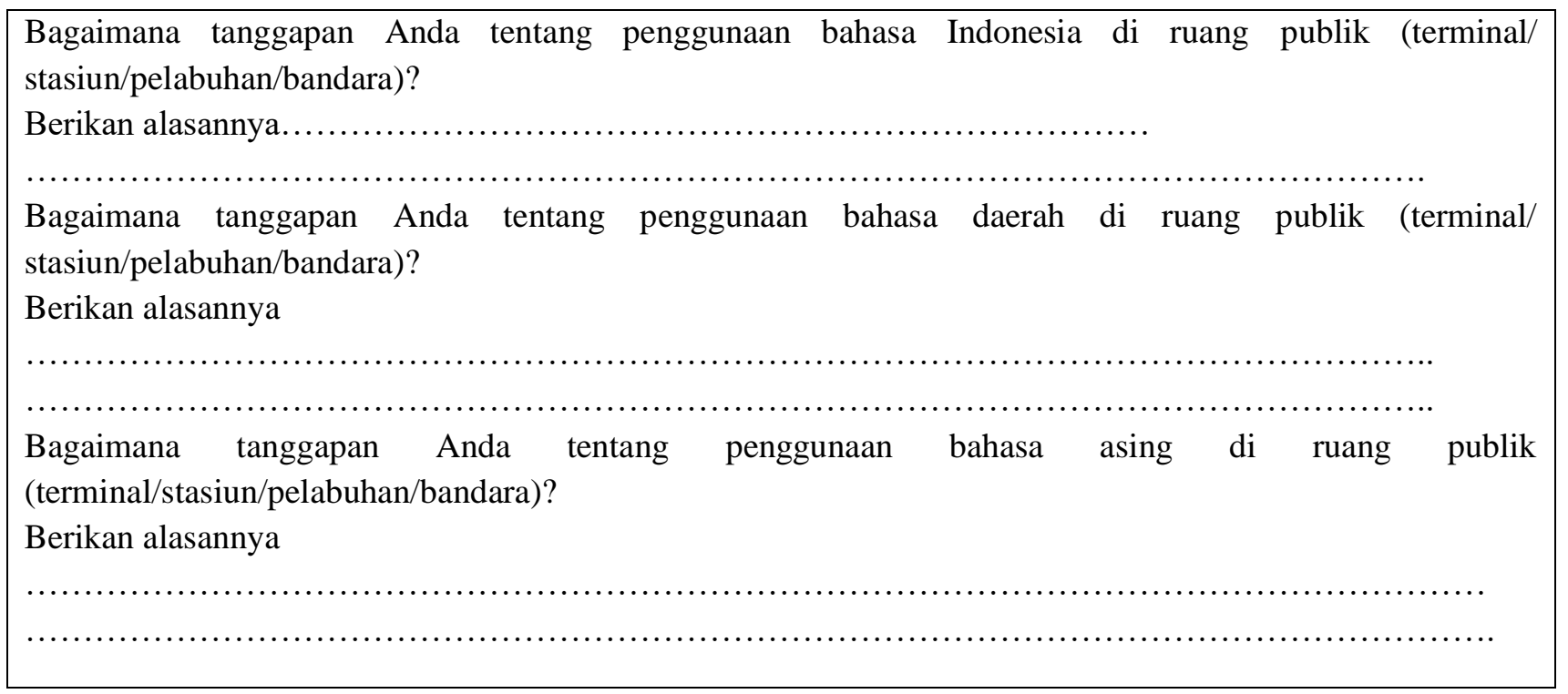


LAMPIRAN 2: Foto-foto di lapangan

LAMPIRAN 2: Moda Transportasi Udara

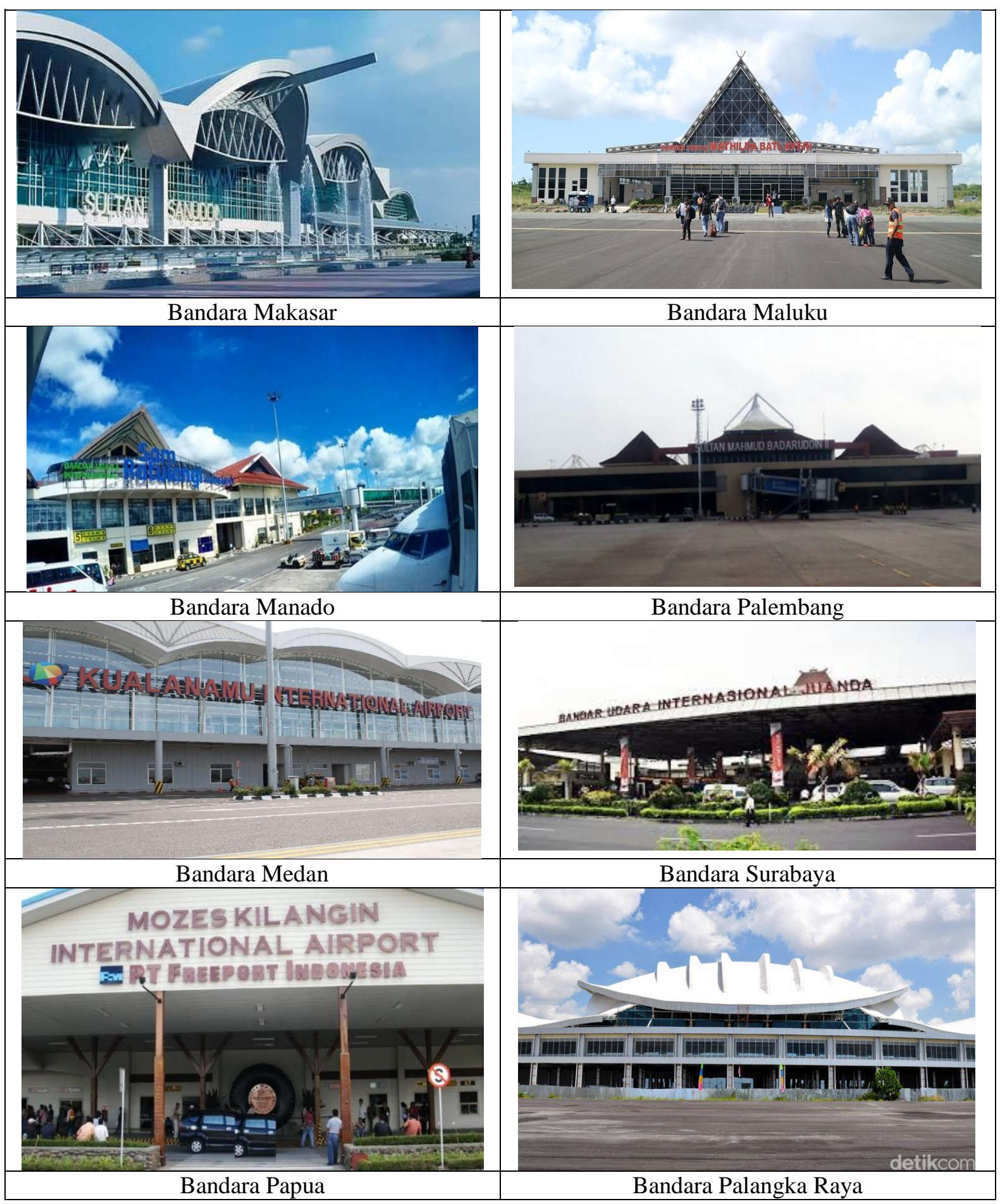




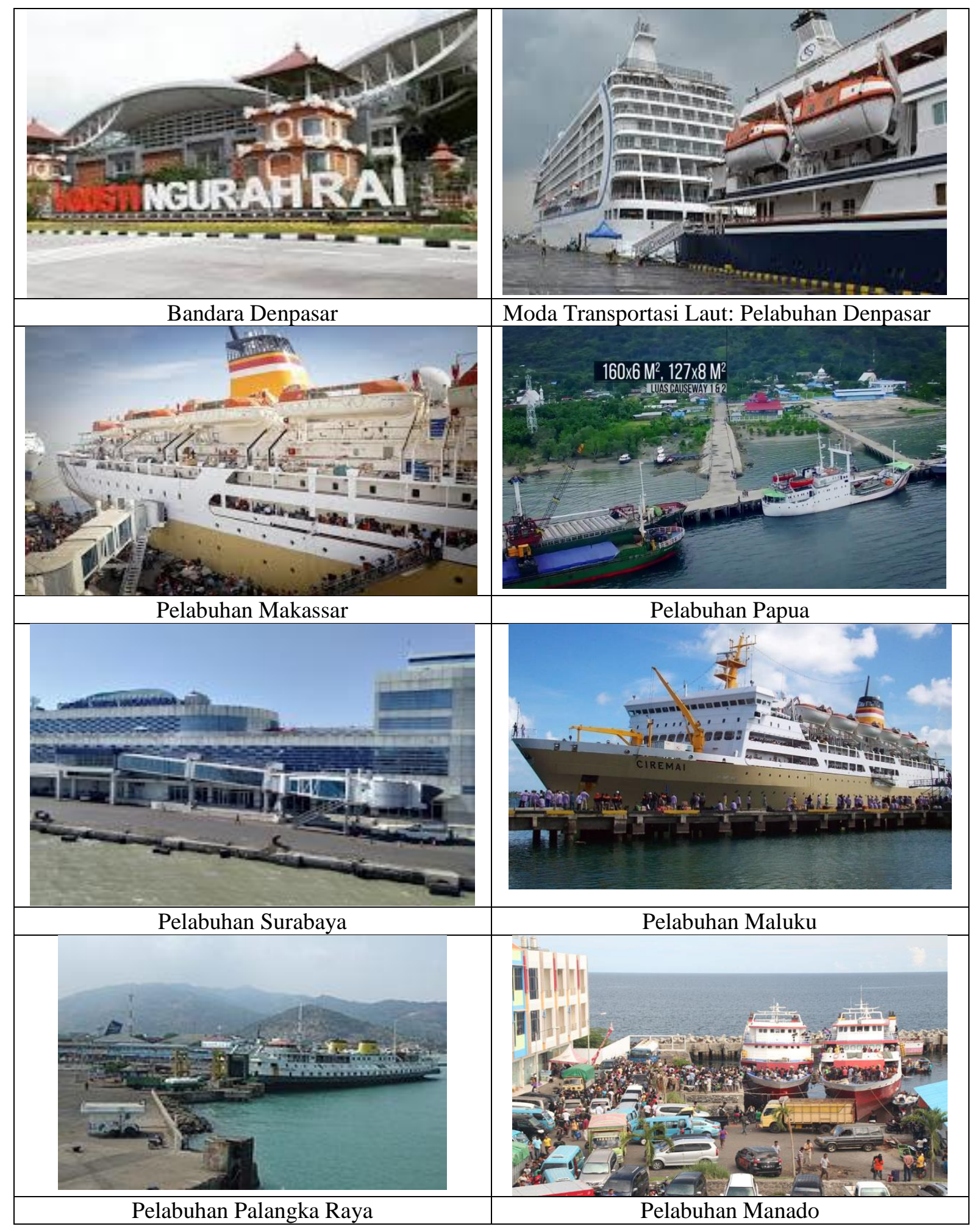




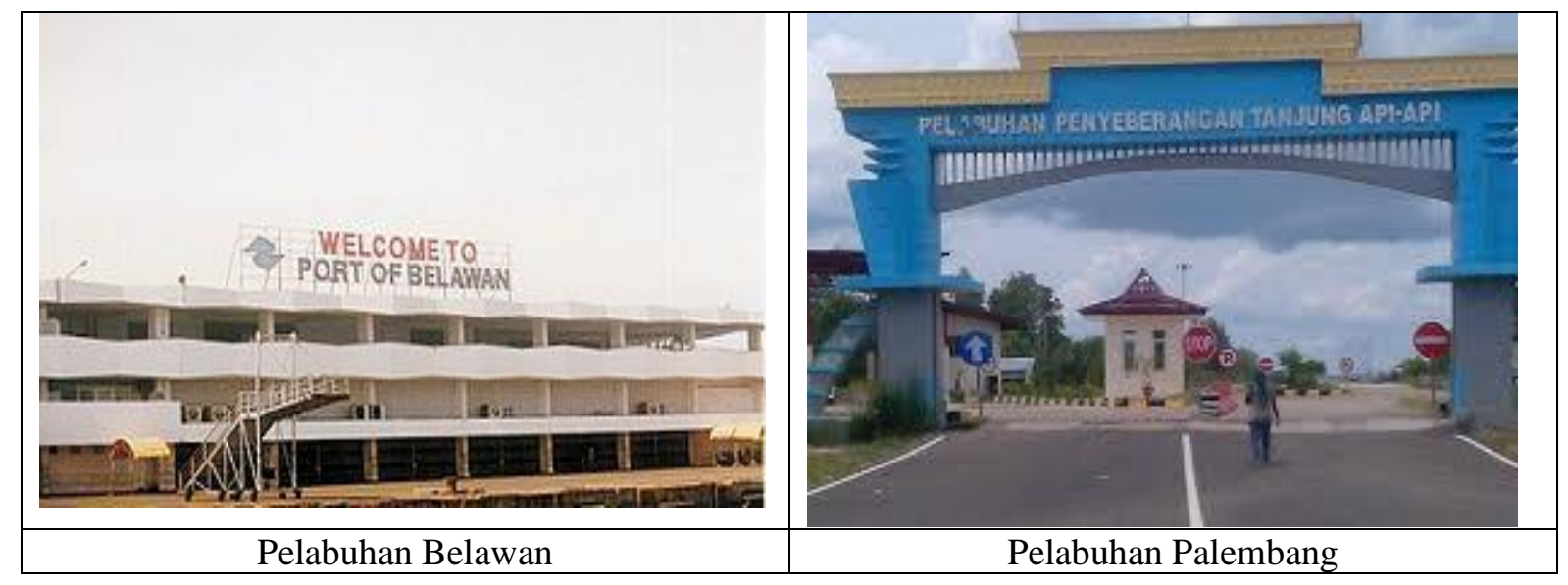

